Environment, Biodiversity \& Soil Security
(EBSS)
http://jenvbs.journals.ekb.eg//

\title{
Removal of Potentially Toxic Elements (PTEs) from Contaminated Water Using Microcrystalline Cellulose Extracted from Rice Straw
}

\author{
Hassan Abbas', Mamdouh F. Abdelsabour ${ }^{2}$, Mohamed A. Abdelsalam', Maha E. \\ Ali $^{1}$ and Omar S. Khalifa ${ }^{2 *}$ \\ ${ }^{1}$ Soils and Water Department, Faculty of Agric., Benha University, Egypt \\ ${ }^{2}$ Soil and Water Researches Dept., Nuclear Researches Center, Egyptian Atomic \\ Energy Authority, Egypt
}

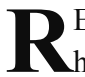
EUSING wastewater as an additional resource of water in Egypt always be facing by high load of contaminants, especially potentially toxic elements (PTEs). Sorption of PTEs is one of the technologies used for treatment wastewater. Cellulose derived materials, like microcrystalline cellulose, can be used for removal of PTEs. In this study, microcrystalline cellulose prepared from rice straw with an eco-friendly method and tested for $\mathrm{Pb}, \mathrm{Cd}$, and $\mathrm{Cu}$ removal from artificial contaminated water. Factors affecting metal ions removal were also investigated. Obtained results showed that the removal efficiency of the PTEs was 94, 72, and $89 \%$ for $\mathrm{Pb}, \mathrm{Cd}$, and $\mathrm{Cu}$, respectively at $10 \mathrm{mg} \mathrm{L}^{-1}$ of microcrystalline cellulose. Removal of $\mathrm{Cd}$ and $\mathrm{Cu}$ decreased with increasing of initial concentration up to $200 \mathrm{mg} \mathrm{L}^{-1}$, however, for $\mathrm{Pb}$ the removal efficiency was near $90 \%$ till initial concentration $150 \mathrm{mg} \mathrm{L}^{-1}$. In summary, the prepared microcrystalline cellulose were shown as promising adsorbents can assist PTEs from contaminated wastewater.
\end{abstract}

Keywords: Potentially toxic elements (PTEs); Microcrystalline cellulose (MCC); Contamination removal; Lead; Cadmium; Copper

\section{Introduction}

Over the years, deterioration of the water quality observed due to anthropogenic activities, fast industrial progress and inexpert application of water resources (De Gisiet al. 2016; Bassouny and Abbas, 2020 and Bassouny et al. 2020). ChoukrAllah (2010) and Elbanaet al. 2017 reviewed that Egypt had $68.30 \mathrm{~B} \mathrm{~m}^{3} /$ year total water withdrawal, the great River Nile is the main water provider in Egypt is limited to $55.5 \mathrm{~B} \mathrm{~m}^{3}$ /year. Whereas, $3.76 \mathrm{~B} \mathrm{~m}^{3} /$ year wastewater production, and $2.97 \mathrm{~B} \mathrm{~m}^{3} /$ year treated wastewater in the first years of this century were reported. In addition, the most of the treated wastewater is reused to irrigate edible and non-edible crops, especially wood trees. Attia (2004) reported that the largest consumer of water in Egypt is the agricultural sector, (more than $80 \%$ of water demand). The agricultural sector consumed $62.4 \mathrm{~B} \mathrm{~m}^{3}$, while the drinking and healthy uses consumed 10.4 B $\mathrm{m}^{3}$. Wastewater recycling provided $1.3 \mathrm{~B} \mathrm{~m}^{3}$. As reviewed by Ahmad et al.(2020) and Asano et al.(2018), wastewater can be categorized into two categories based upon its derivation: domestic and industrial wastewaters. Industrial liquid wastes being drained which generate industrial wastewater having various components like FOG (fat, oil and grease), pharmaceutical wastes, chemicals, and other hazardous materials.

Potentially toxic elements (PTEs) are among the most enduring contaminant in water (Elshazlyet al. 2019). In contrary other pollutants, they are incapable of being chemically degraded, thus, accumulate through the food chain (Hashimet al. 2017and Mohamed et al. 2018), causing potential hazard on human health and environmentally troubles (Abdelhafezet al. 2012 \& 2015). PTEs reached to water bodies may be due to discharges

"Corresponding author: E-mail: osmkhalifa31@gmail.com

Authors' Emails: hharsalem@yahoo.com; wise2007egy@yahoo.com; mohamedalysalam@yahoo.com;

maha.ali@fagr.bu.edu.eg; osmkhalifa31@gmail.com

Received 19/12/2020; Accepted 8/1/2021

DOI: $10.21608 /$ jenvbs.2021.54230.1124

(C)2021 National Information and Documentation Center (NIDOC) 
from urban towns; some industrial discharge especially chemical industries like fertilizers, pharmaceutical, textile and pesticides (El. Nonoet al. 2015 and Mosaet al. 2017). Abdel-Sabour et al. (1996), Hassan et al. (2013), Ali et al. (2016), Ibrahim et al. (2016), El-Ramady et al. (2017) and Farid et al. (2019) reported that sewage effluent has been used for crop irrigation for many years and its use is increasing particularly in water-short areas. Sewage effluent can be a useable water resource if suitable precautions are taken.

Therefore, searching for sustainable materials that can decontaminate PTEs from water became a necessity. One of these materials is cellulosic materials. Cellulose is a crystallization material with abundance of hydroxyl groups (Fathy et al. 2015). Thakur et al. (2020) reported that rice straw is usually of less importance because of its very low nutritive value and its combustion for removing its residue from agricultural lands, produces a enormous amount of ash and other hazardous materials. The major constitute of rice straw includes cellulose $(38.3 \%)$, hemicellulose $(31.6 \%)$, lignin $(11.8 \%)$, and silica (18.3\%). Thakur et al.(2020) added that there are several adverse effects on the environment due to the open burning of rice straw. For instance, the burning of rice straw conducting to loss of important soil nutrients and can causes a scarcity in soil microbes. Another effect of straw burning is the smokescreen which leads to high risk on mankind life.

Therefore, the utilization of extracted cellulose and its derivatives from rice straw and other agricultural wastes represented an important subject for researchers. Microcrystalline cellulose (MCC), as described by Järvenpää (2019) is almost white and odorless purified cellulose produced from different lignocellulose sources by various techniques such as acid hydrolysis. Ibrahim et al. (2013) used rice straw and banana plant waste to prepare MCC. Microcrystalline cellulose usage for water and wastewater treatment was discussed in some studies. For example, Garba et al. (2019) reviewed that cellulosic materials can form several complexes with PTEs. Therefore, this study aims at using rice straw as an agricultural waste to synthesize microcrystalline cellulose as

TABLE 1. Rice straw constituents a cheap adsorbent for removing $\mathrm{Pb}, \mathrm{Cd}$, and $\mathrm{Cu}$ from artificial contaminated waters.

\section{Materials and Methods}

Laboratory experiments were conducted in the Soil and Water Research Department, Nuclear Research Center, Atomic Energy Authority, Egypt. Rice (Oryza sativa) straw (RS) was brought from a local field at El-Sharquia government, Egypt. Straw was cleaned with tab water twice to remove dirt and once with distilled water, then dried at $70^{\circ} \mathrm{C}$ for $24 \mathrm{hr}$, and preserved in a cool dry place. Chemical constituents of the straw are listed in Table 1.

\section{Chemicals}

Lead nitrate $\mathrm{Pb}\left(\mathrm{NO}_{3}\right)_{2}$ (assay 99.5\%, MW: 331.21), cadmium chloride $\mathrm{CdCl}_{2}$ (assay 99\%, MW: 183.31 ) and copper sulfate $\mathrm{CuSO}_{4} .5 \mathrm{H} 2 \mathrm{O}$ (assay 98\%, MW: 249.68) for preparation metal ion solutions. All these reagents were AR (Analytical Reagent) grade chemicals. Also, $\mathrm{H}_{2} \mathrm{SO}_{4}, \mathrm{H}_{2} \mathrm{O}_{2}$, which were used for synthesis experiments were AR grade. $\mathrm{NaCl}$ and $\mathrm{NaOH}$ are used as technical grade for synthesis of MCC.

\section{Synthesis of sorbent materials}

Twenty grams of washed and dried rice straw (RS) was added to $600 \mathrm{~mL}$ of $1 \% \mathrm{H}_{2} \mathrm{SO}_{4}$ and boiled for 45 min then the straw was detached and washed with abundant water till $\mathrm{pH}$ turned to neutral and the filtrate was dumped. The acidtreated RS from the last step was added to 600 $\mathrm{mL}$ of $1.5 \mathrm{M}$ of $\mathrm{NaOH}(6 \% \mathrm{~W} / \mathrm{V})$ and $5 \%(\mathrm{~V} / \mathrm{V})$ $\mathrm{H}_{2} \mathrm{O}_{2}$ and boiled for 30 minutes, then filtered and washed with abundant water. This step was for silica and lignin removal with alkali treatment. Because of $\mathrm{H}_{2} \mathrm{O}_{2}$ addition, the filtrate color was yellow, the alkali treatment without oxidation agent $\left(\mathrm{H}_{2} \mathrm{O}_{2}\right)$ always produces black liquor and the fibers produced with $\mathrm{H}_{2} \mathrm{O}_{2}$ addition were of a lighter color than those produced without it. To bleach fibers to synthesis white MCC, fibers from alkali treatment added to $0.5 \mathrm{~L}$ of $0.5 \% \mathrm{NaClO}$ and boiled for $30 \mathrm{~min}$, then filtrate and washed with abundant water, dried in air and ambient laboratory temperature for two or three days depending on ambient temperature and moisture in MCC. Then, ground with a household grinder. This method is according to Nassar and El Shakankery (2014) with a slight modification.

\begin{tabular}{cccccc}
\hline Constituent & $\alpha$-Cellulose & Lignin & Hemicelluloses & Ash & Silica in ash \\
\hline$\%$ & 70.1 & 1.34 & 17.8 & 13.8 & 72.1 \\
\hline
\end{tabular}




\section{Materials characterization}

\section{FTIR, XRD, EDX, SEM}

Active groups in MCC were characterized using FT-IR spectroscopy (Fourier-transform infrared spectroscopy) using an FTIR - (Model: 8201 PC), Shimadzu, Japan. XRD (X-ray diffraction) was used to determine the crystallinity of the rice straw fiber and MCC was analyzed by Bruker (Model: D2 Phaser)-USA X-ray diffraction meter with a $\mathrm{CuKa}$ radiation source. The measurements were performed at a step size of $0.02^{\circ}$ in a $2 \theta$ angle range of $10^{\circ}$ to $40^{\circ}$. The crystallinity index (CrI) was calculated by using the peak area method. Also, to determinechemical composition and surface graphical imagining of the prepared material, MCC was analyzed by Philips (Model: XL 30)-USA Scanning Electron Microscope SEM with the attached EDX (Energy Dispersive X-Ray Analyzer) Unit.

\section{Adsorption experiments}

Factors affecting removal of PTEs using MCC were studied by conducting of batch techniques. Batch experiments were carried out in $100 \mathrm{~mL}$ Erlenmeyer flasks at $25^{\circ} \mathrm{C}$ and 300 $\mathrm{rpm}$. A weighed amount $(0.10 \mathrm{~g})$ of adsorbent was added to $50 \mathrm{~mL}$ of metal solutions of varying concentrations which differ between 10 and 200 $\mathrm{mg} \mathrm{L}^{-1}$ (i.e.: 0, 10, 20, 30, 50, 70, 100, 150 and $200 \mathrm{mg} \mathrm{L}^{-1}$ ) each time and shaken continuously for $3 \mathrm{hr}$ to achieve equilibrium. The mixtures were centrifuged and the concentrations of metal ions $(\mathrm{Pb}, \mathrm{Cd}$, and $\mathrm{Cu})$ were determined by AAS method using a atomic absorption spectrophotometer (AAS)- GBC, (Model: 902)-Australia. Then, experiment to determine effects of $\mathrm{pH}$ (differed between 3 to 7 with stepwise with 1). The applied $\mathrm{pH}$ values of the solutions were adjusted using a dilute solution of either $\mathrm{NaOH}$ or $\mathrm{HCl}$ of $0.01 \mathrm{M}$. That was using $0.1 \mathrm{~g}$ of MCC with $50 \mathrm{~mL}$ of 10 $\mathrm{mg} \mathrm{L}^{-1}$ of each studied PTEs for 180 minutes equilibrium time. The contact time (10-360 $\mathrm{min}$ ). For this experiment, $0.1 \mathrm{~g}$ of $\mathrm{MCC}$ with $50 \mathrm{~mL}$ of $10 \mathrm{mg} \mathrm{L}^{-1}$ of each studied PTEs for each studied equilibrium time was used. Adsorbent/solution ration experiment was conducted with $2.5-100 \mathrm{~g}$ $\mathrm{L}^{-1}$. For this experiment, certain weights of MCC with $50 \mathrm{~mL}$ of $10 \mathrm{mg} \mathrm{L}^{-1}$ of each studied PTEs for 180 minutes equilibrium time was used.

\section{Calculation}

In all experimental runs, the sorbed ion amounts were calculated as follows:

Removal percentage $(\mathrm{R} \%)=$.

Where $C_{0}$ and $C_{e}$ are the concentrations $\left(\mathrm{mg} \mathrm{L}^{-1}\right)$ of each ion before and after sorption, respectively.

\section{Statistical analysis}

Data of the current study were statistically analyzed using Statistical Software Program (PCMstat). Means of treatments were compared with the Least Significant Deference (L.S.D) at the 0.05 level.

\section{Results and Discussion}

Characterization of MCC as a sorbent material

The FT-IR spectrum of the MCC is given in Fig. 2. FT-IR spectrum of MCC materials have identified the presence of several surface functionalities such as the peak at wavenumber $1055 \mathrm{~cm}^{-1}$ for hydroxyl groups. The peak at 1729 $\mathrm{cm}^{-1}$ refers to the presence of carboxylic groups and $3352 \mathrm{~cm}^{-1}$ which found for the vibration of phenols. These functional groups can help in the sorption of ion contaminants, including PTEs.

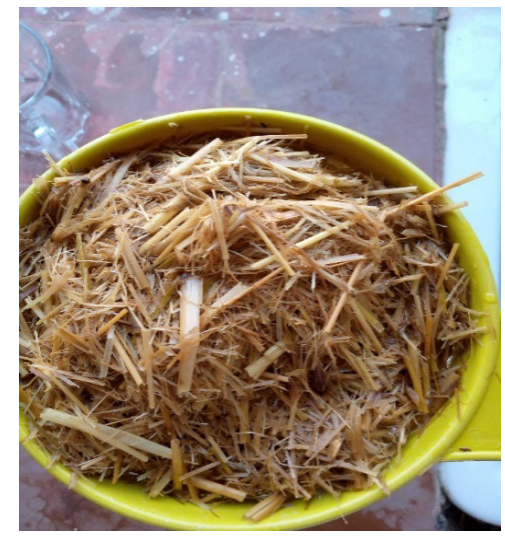

Acidified RS

$\left(1 \% \mathrm{H}_{2} \mathrm{SO}_{4}\right) / 45 \mathrm{~min}$

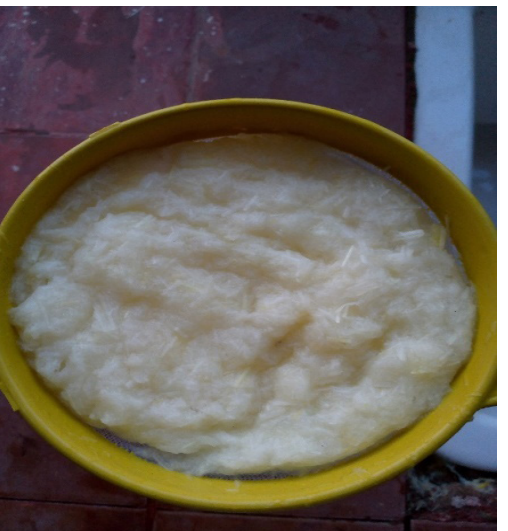

Alkaline treatment $\left(\mathrm{NaOH}+\mathrm{H}_{2} \mathrm{O}_{2}\right) / 45$ $\min$
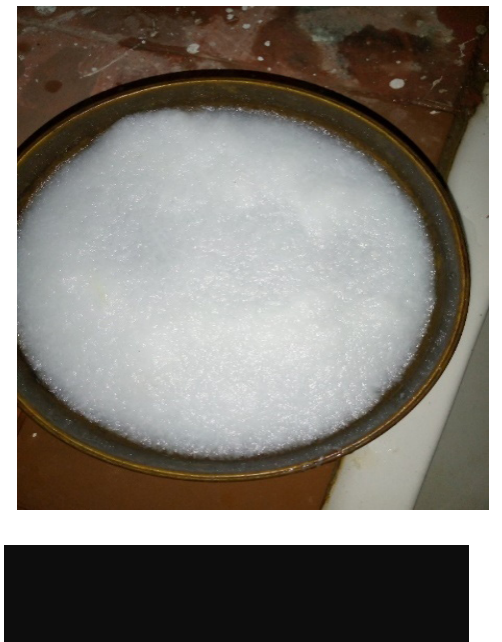

Fig. 1. The preparation steps of the sorbent 
MCC crystallinity degree can be determined from the interpretation of XRD diffraction patterns of MCC shown in Fig. 3. The characteristic peaks occurred at $16.5^{\circ}$ and $22.5^{\circ}$ are expressed to cellulose crystal lattice structure. Calculated Crystallinity index (CI) was 40\%. These results are similar to that found by Chin et al. (2013).

SEM images of the MCC are illustrated in Fig. 4. It can be seen that the morphology of the cellulose fibers and MCC. This is due to the success of the removal of the other untreated cellulose materials. Results of EDX analysis for MCC, showed that carbon and oxygen are the main components, however, silica and calcium were detected at lower levels. Similar results were reported by Chin et al. (2013) on MCC extracted from RS, Kunusa et al. and (2018) on MCC extracted from corncobs with $6 \% \mathrm{NaOH}$ alkaline treatment.
Factors affecting removal of heavy metals under investigation using $M C C$

\section{Initial concentration}

Adsorption experiments were conducted with differed initial metal ion concentrations from 0 to $200 \mathrm{mg} \mathrm{L}^{-1}$ using $2 \mathrm{~g} \mathrm{MCC} \mathrm{L}^{-1}$. Results illustrated in Fig. 5 show that MCC was effective in the removal of $\mathrm{Cu}$ and $\mathrm{Cd}$ diluted concentrations (i.e. 10 and $20 \mathrm{mg}$ PTEs $\mathrm{L}^{-1}$ ), however, lead removal percentages were the highest (ranged from 94 to $90 \%$ ) until $150 \mathrm{mg} \mathrm{L}^{-1}$ of lead in the initial solution, thereafter decreased to $63 \%$ at $200 \mathrm{mg}$ $\mathrm{L}^{-1}$. Cadmium and copper removal (expressed as a percentage of initial concentration) decreased sharply from 67 to $15 \%$ and 89 to $11 \%$ for 10 to $70 \mathrm{mg} \mathrm{L}^{-1}$ initial concentration for $\mathrm{Cd}$ and $\mathrm{Cu}$, respectively. Removal percentages of $\mathrm{Cd}$ and $\mathrm{Cu}$ at initial metal ion concentrations from 100 to 200 $\mathrm{mg} \mathrm{L}^{-1}$ didn't have wide changes.

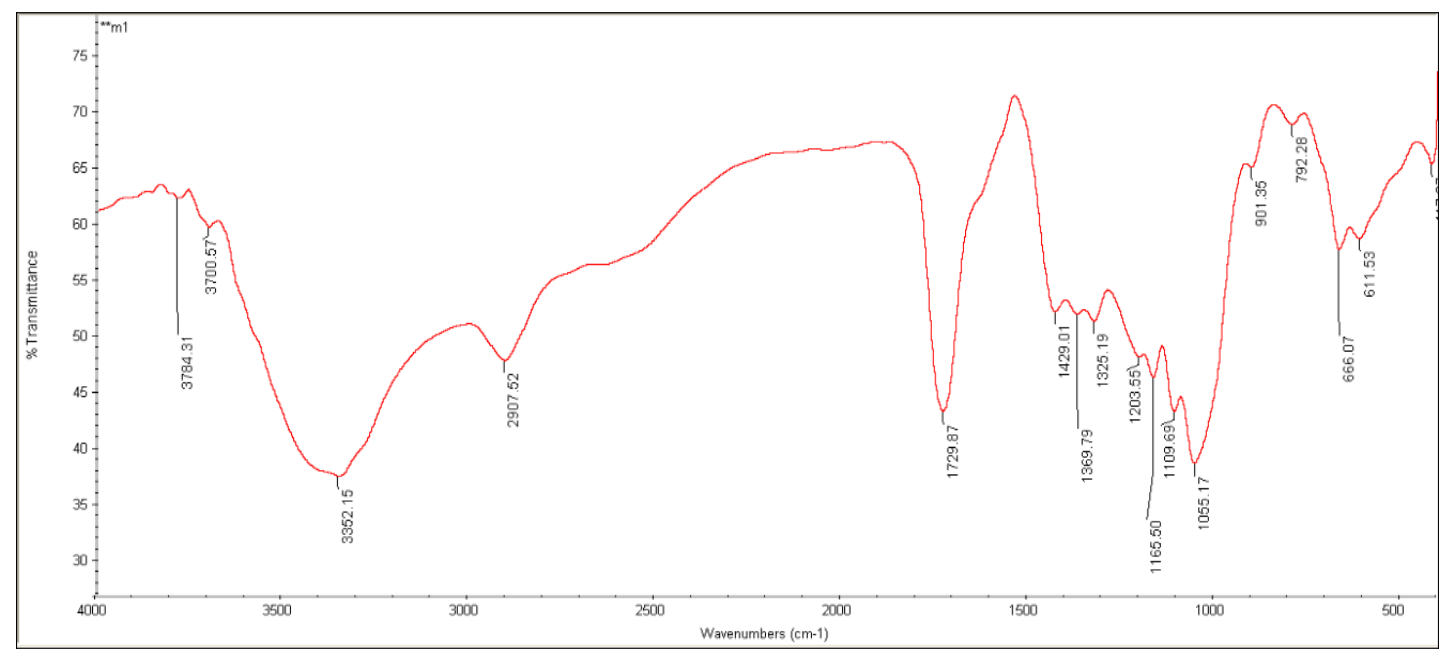

Fig. 2. FT-IR characterization of MCC

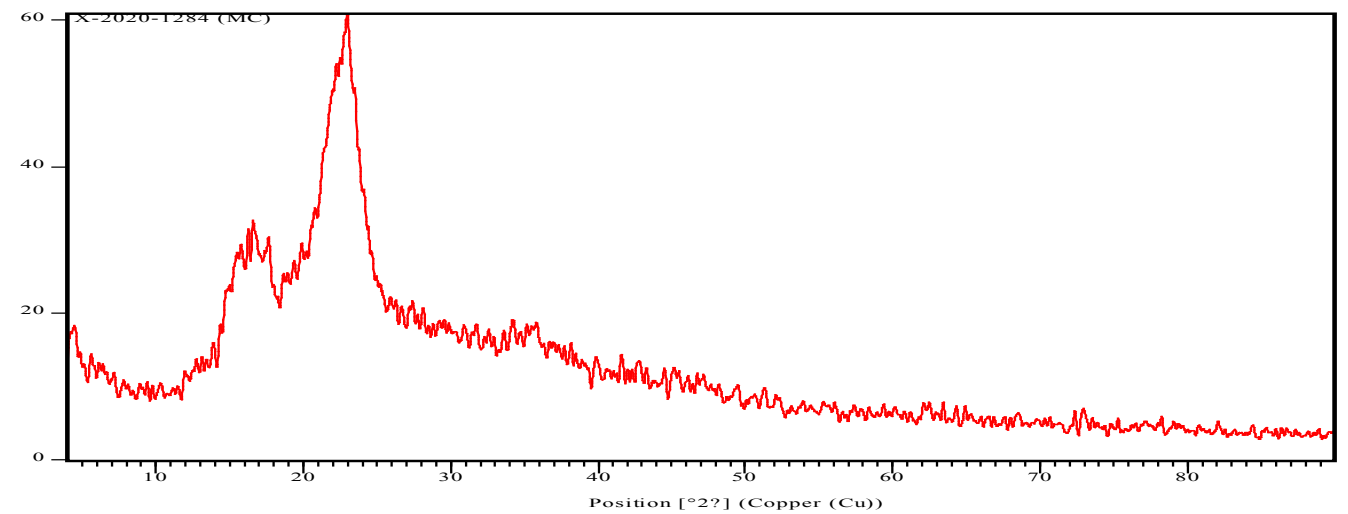

Fig. 3. XRD characterization of MCC 
Resulted data is detailed in Table 2 which showed that significant effect of initial metal ion concentration on removal of PTEs using MCC. These results were similar to those reported by Garba et al. (2019)who reported that the sorption data showed that the removal percentages for $\mathrm{Pb}^{2+}, \mathrm{Cu}^{2+}$, and $\mathrm{Cd}^{2+}$ with an initial metal ion concentration of $10 \mathrm{mg} \mathrm{L}^{-1}$ were $93.2 \%, 87.5 \%$, and $72.3 \%$, respectively, and that was attained within $5 \mathrm{~min}$.

\section{Effect of $\mathrm{pH}$ on the adsorption of studied PTES}

Figure 6 shows the impact of $\mathrm{pH}$ on the removal of $\mathrm{Pb}^{2+}, \mathrm{Cd}^{2+}$ and $\mathrm{Cu}^{2+}$ at a $\mathrm{pH}$ ranging from 3-7. The percentage removal was found to increase progressively with increasing $\mathrm{pH}$ and reaches to the highest value at $\mathrm{pH} \mathrm{7,6}$ and 5 for $\mathrm{Pb}, \mathrm{Cd}$ and $\mathrm{Cu}$ ions, respectively. After $\mathrm{pH} 5$, each metal ion behaved differently. Lead removal increased with increasing $\mathrm{pH}$ value, until $\mathrm{pH} 7$ while cadmium removal decreased till $\mathrm{pH} 7$, Whereas copper removal increased until $\mathrm{pH} 6$, then decreased. The solution $\mathrm{pH}$ may change the surface charge of the adsorbent material and the ionization degree as well as the surface functional groups (Anah and Astrini, 2017). Similar trends of metals removal were observed by Singha and Guleria (2014) for $\mathrm{Pb}, \mathrm{Cd}, \mathrm{Cu}$, and $\mathrm{Zn}$ sorbed by cellulosic fibers. Deshmukh et al. (2017) described cadmium sorption on cellulosic materials as follows: In low $\mathrm{pH}$ values, $\mathrm{Cd}^{+2}$ compete with $\mathrm{H}^{+}$for binding sites therefore. Increasing in the rate of metal removal was observed at a $\mathrm{pH}$ ranged from 4 to 7 . Metal removal may not involve complete sorption in this $\mathrm{pH}$ range. Kaur et al. (2020) reported the same trend of lead removal which was found to depend on $\mathrm{pH}$ level using cellulosic material.

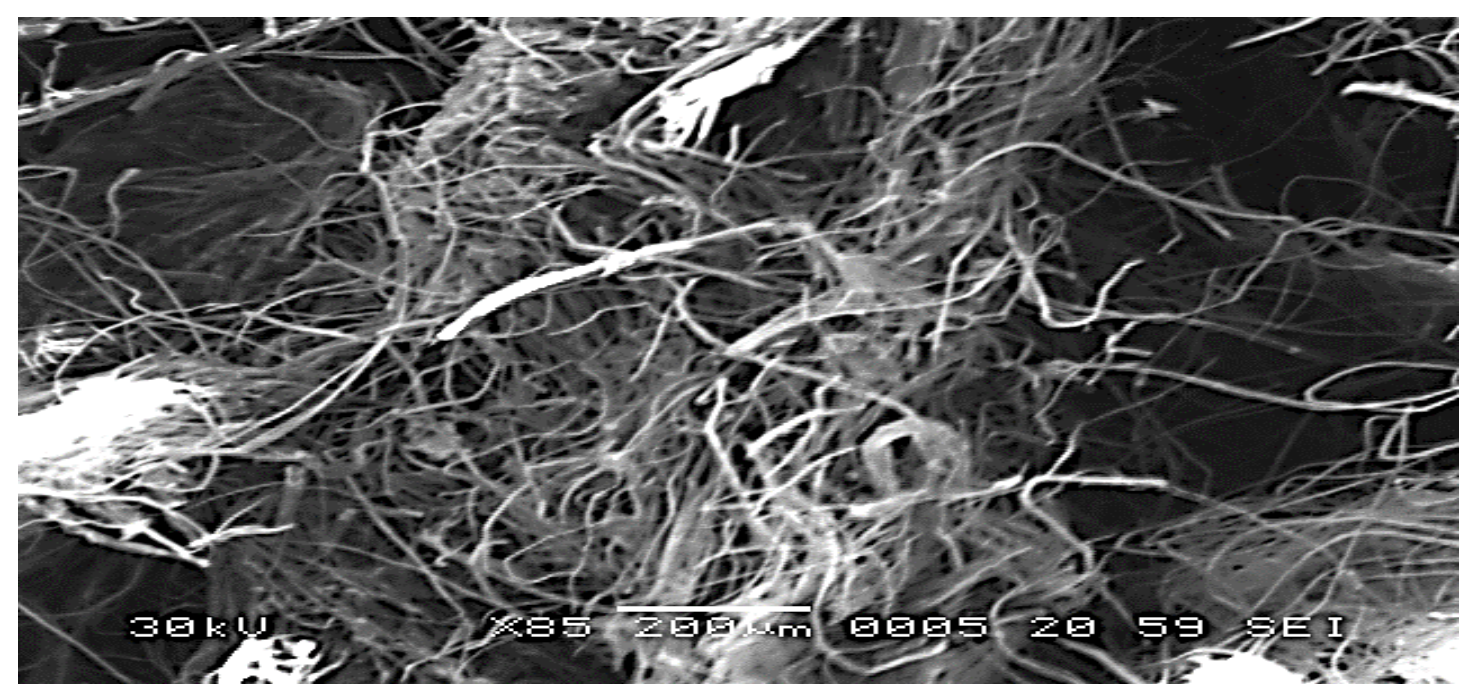

Fig. 4. SEM characterization of MCC

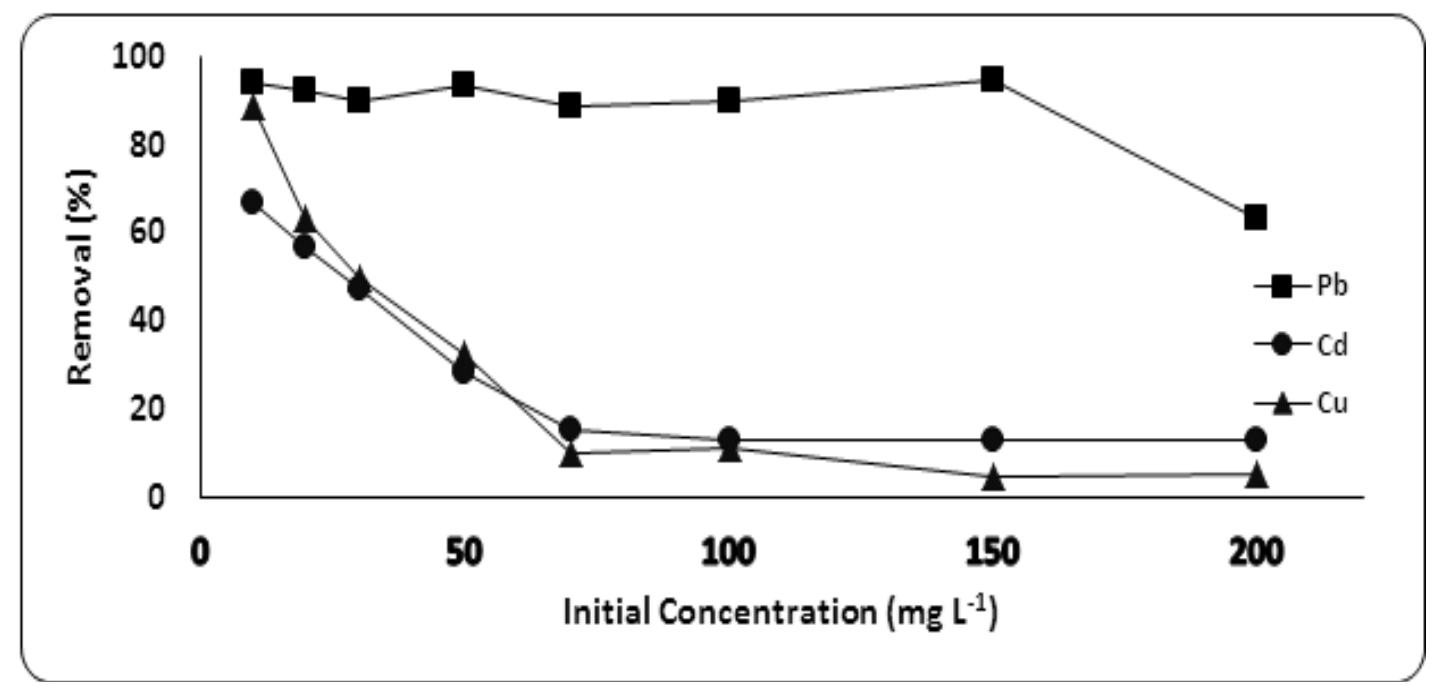

Fig. 5. Effect of solution initial metal ion concentration (mg L-1) on removal of the PTEs lead, Cadmium and Copper from their aqueous solutions using Microcrystalline cellulose MCC. 


\section{Effect of contact time}

The effect of time of contact on the sorption of $\mathrm{Pb}, \mathrm{Cd}$ and Cuions is shown in Fig. 7. The results show that increase in the contact time (from 10 to 360 minutes) increased of the metal ions removal and it persisted constantly after the equilibration time of $30 \mathrm{~min}$. Therefore, the optimum agitation period of metal sorption was near to 30 minutes. Similar results were reported for modified MCC$\mathrm{Pb}$ sorption by $\mathrm{Fu}$ and $\mathrm{Xie}$ (2020) found that equilibrium time was about 30 minutes under high concentration (100-200 $\left.\mathrm{mg} \mathrm{L}^{-1}\right)$. For cadmium, El-Naggar et al. (2018) reported similar results, where they found that 20 to 40 minutes was enough to reach equilibrium on MCC aerogel. For copper, Abdel-Halim, and Al-Deyab (2012) reported equilibrium time for sorption $\mathrm{Cu}$ on MCC was about 30 minutes.

\section{Effect of sorbent dose}

Results in Fig. 8, show that sorbed amounts of metal ions per the unit mass of sorbent reduced with increasing sorbent/solution ratio (g MCC $\mathrm{L}^{-1}$ ) for all the PTEs under investigation. Some other studies indicated that, the removal percentages seemed to follow an opposite trend, where they found that sorption increased with increasing sorbent dose from 2.5 to $100 \mathrm{~g} \mathrm{~L}^{-1}$ (El-Naggaret al. 2018). The decrease occurred in sorbed metal ions per the unit mass of the sorbent is probably because more sorbent amounts mean more available sites for sorption of the metal ions whose initial concentration was constant. Therefore, a pronounced number of sorption sites is expected to be free of sorbed ions. While the increase of lead removal using MCC reached near $100 \%$ at a $100 \mathrm{~g} \mathrm{~L}^{-1}$ dose of sorbent, cadmium removal reached about $90 \%$ at the same dose of the sorbent i.e. $100 \mathrm{~g} \mathrm{~L}^{-1}$ dose. Copper removal did not reached more than $80 \%$ at the maximum studied sorbent dose. Similar trends were recorded by many researchers, for example, cadmium removal described as the same with Deshmukh et al. (2017).

TABLE 2. Effect of initial PTEs concentrations $\left(\mathrm{mg} \mathrm{L}^{-1}\right)$ on removal (\%) of the studied PTEs using MCC with statistical analysis

\begin{tabular}{lccccccccc}
\hline \multicolumn{10}{c}{ Initial metal ion concentrations $\left(\mathrm{mg} \mathrm{L}^{-1}\right)(\mathrm{C})$} \\
\hline & 10 & 20 & 30 & 50 & 70 & 100 & 150 & 200 & Mean \\
\hline $\mathrm{Pb}$ & 94.04 & 92.10 & 90.00 & 93.40 & 89.00 & 90.10 & 94.87 & 63.25 & 88.83 \\
$\mathrm{Cd}$ & 67.00 & 57.17 & 47.67 & 28.40 & 15.67 & 13.47 & 13.20 & 13.20 & 31.97 \\
$\mathrm{Cu}$ & 89.00 & 63.67 & 50.00 & 33.00 & 10.43 & 11.27 & 4.80 & 5.50 & 33.46 \\
Mean & 83.35 & 71.61 & 63.22 & 51.60 & 38.37 & 38.28 & 37.62 & 27.32 & 51.42 \\
LSD & $\mathrm{C}-\mathrm{Pb}:$ & 1.547 & & C-Cd: & 0.6594 & & C-Cu: & 0.7705 & \\
\hline
\end{tabular}

L.S.D: Least significant difference

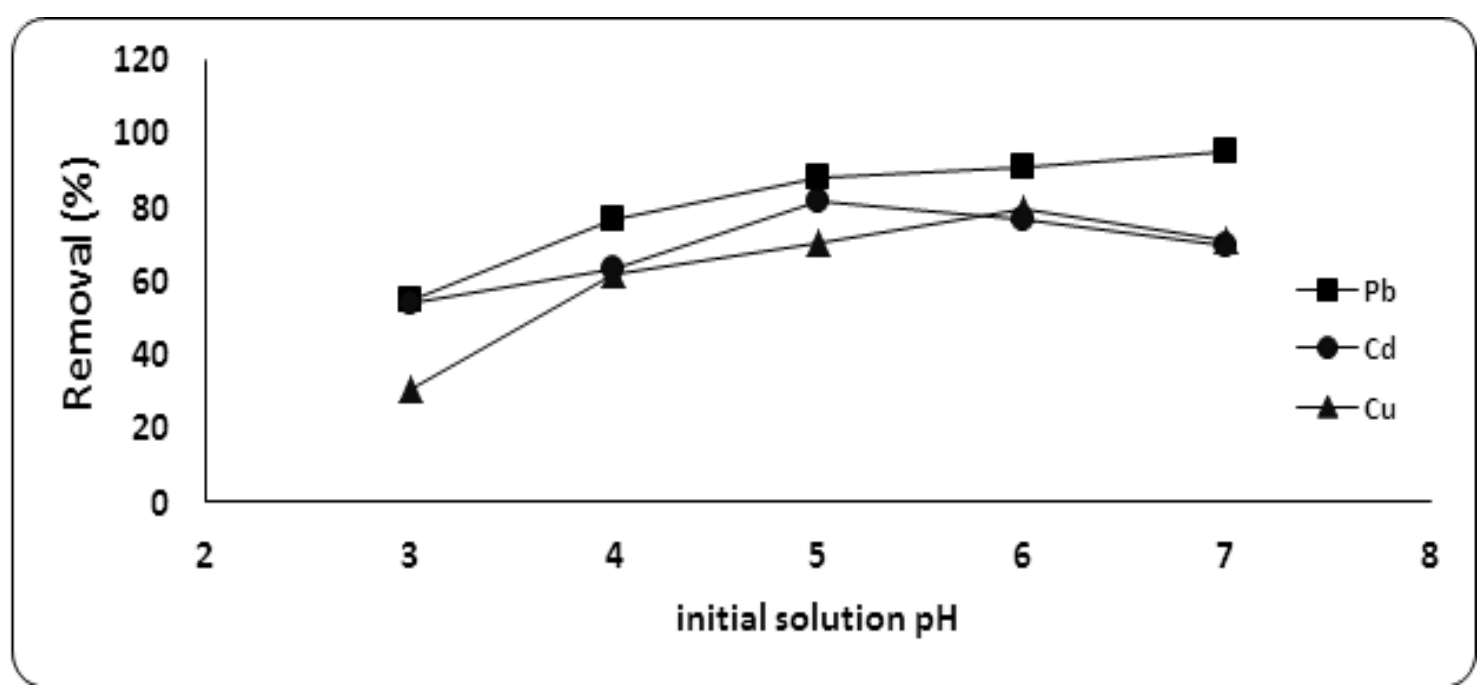

Fig. 6. Effect of $\mathrm{pH}$ of solution on removal of the PTEs $\mathrm{Pb}, \mathrm{Cd}$, and $\mathrm{Cu}$ from their aqueous solutions using Microcrystalline cellulose MCC

Env. Biodiv. Soil Security Vol. 5 (2021) 


\section{Conclusion}

Due to water sacristy in Egypt, reusing of treated wastewater comes to be necessary. Potentially toxic elements one of the most dangerous contaminants in wastewater, because of these nature. Adsorption one of the promising technique to remove PTEs from contaminated water. Cellulose one of the sustainable sources of sorbent materials. Microcrystalline cellulose MCC is one of the successive sorbents. In this study, synthesis of MCC from rice straw with the least amounts of chemicals and least consumed energy for synthesis. Characterization techniques were proved that successive synthesis of MCC using synthesis procedure. Factors affecting the removal of lead, cadmium, and copper was initial concentration with an inverse relationship with removal percentages for $\mathrm{Cd}$ and $\mathrm{Cu}$, but not for $\mathrm{Pb}$. The best $\mathrm{pH}$ for PTEs removal was 7, 6 and for $\mathrm{Pb}, \mathrm{Cd}$, and $\mathrm{Cu}$, respectively. The optimum agitation period of metal sorption was about 30 minutes. An expulsive relationship was found between sorbent dose and removal of PTEs. These results concluded that MCC can be synthesis with eco-friendly methods and effective in usage of MCC, without further additions, for removal of PTEs.

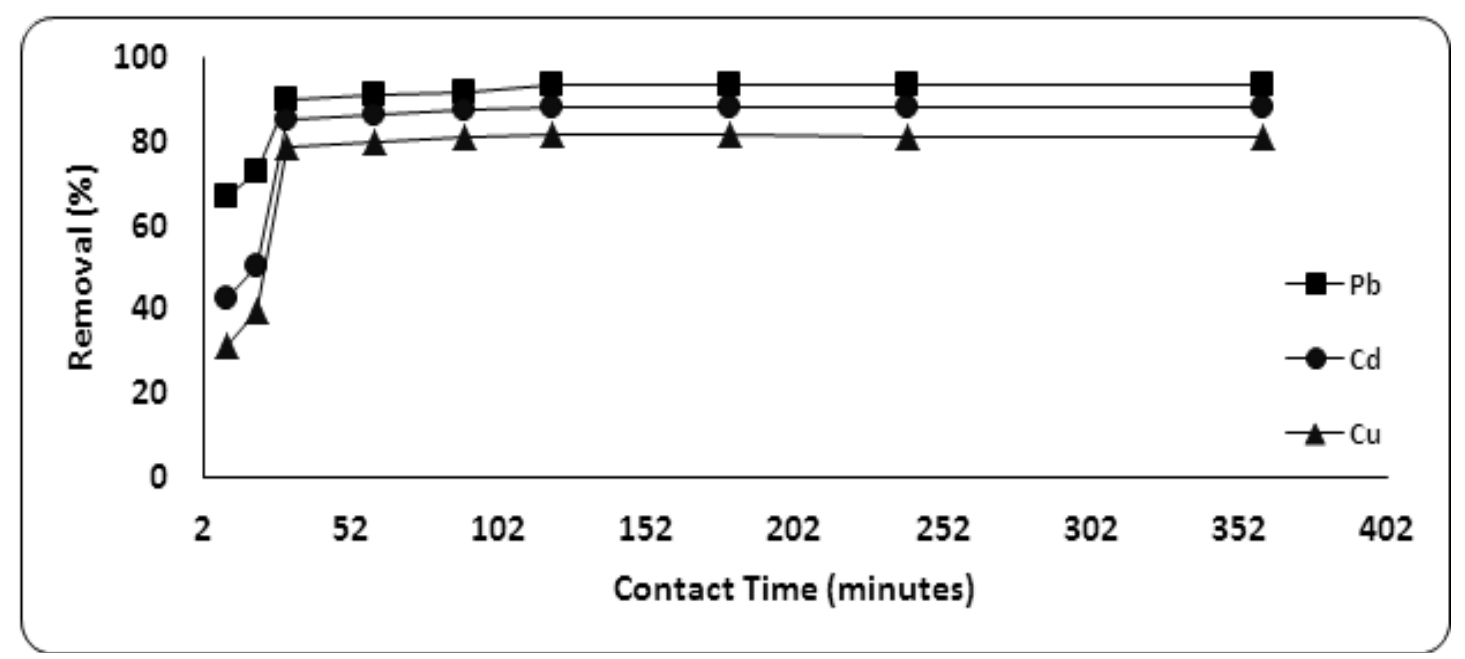

Fig. 7. Effect of contact time (minutes) on the removal of the PTEs ( $\mathrm{Pb}, \mathrm{Cd}$, and $\mathrm{Cu}$ ) from their aqueous Solutions by MCC

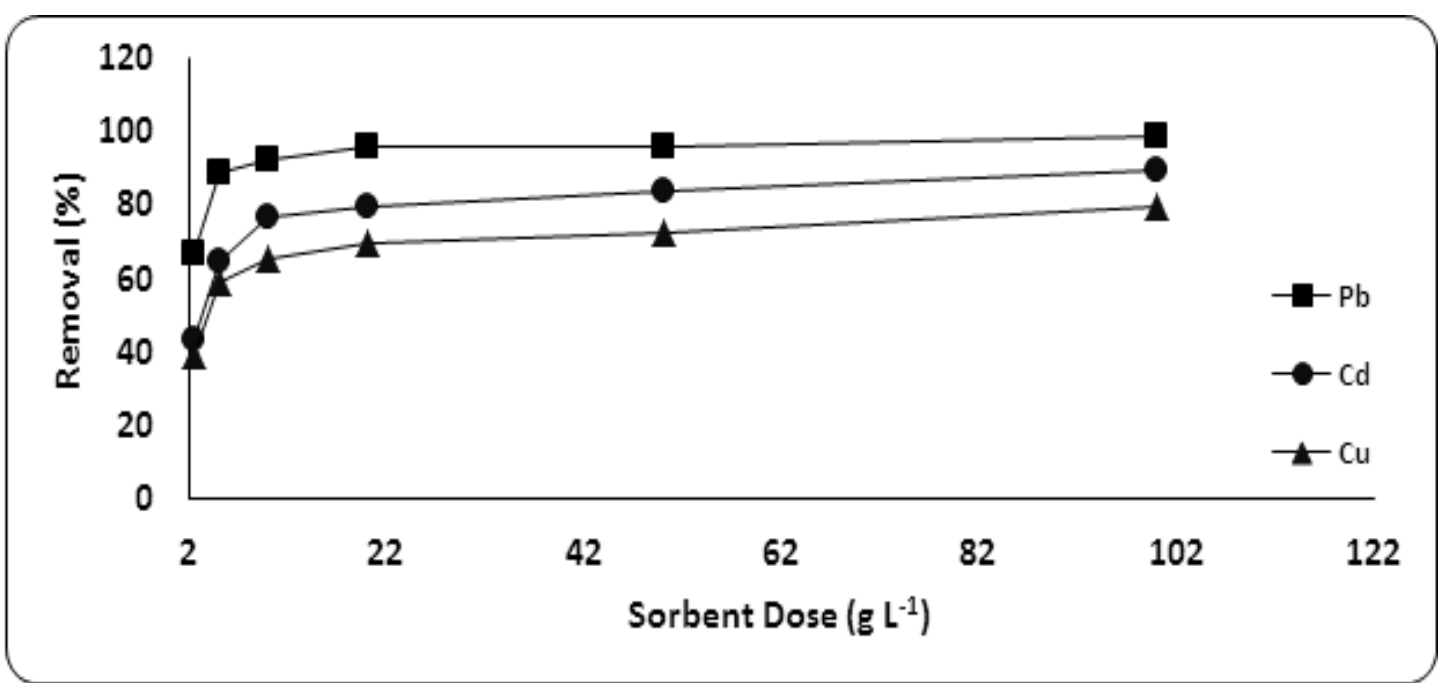

Fig. 8. Effect of contact time (minute) on the removal of the PTEs ( $\mathrm{Pb}, \mathrm{Cd}$, and $\mathrm{Cu}$ ) from their aqueous solutions using MCC 


\section{Ethics approval and consent to participate}

This article does not contain any studies with human participants or animals performed by any of the authors.

\section{Conflict of interest}

There is no conflict between the authors of this study.

\section{Funding}

This research received no external funding

\section{Consent for publication:} tion.

All authors declare their consent for publica-

\section{Author contribution}

All authors of this study shared in all stages from the beginning with idea, design and experimental work up to interpretation of data and edit of manuscript for publication.

\section{References}

Abdelhafez AA, Abbas MHH, Attia TMS (2015) Environmental monitoring of heavy-metals status and human health risk assessment in the soil of Sahl El-Hessania area, Egypt. Pol J Environ Stud. 24 (2), 459-467

Abdelhafez AA, Abbas HH, Abd-El-Aal RS, Kandil NF, Li J, Mahmoud W(2012) Environmental and Health Impacts of Successive Mineral Fertilization in Egypt. CLEAN - Soil, Air, Water, 40 (4): 353-363

Abdel-Halim ES, Al-Deyab SS (2012)Chemically modified cellulosic adsorbent for divalent cations removal from aqueous solutions.Carbohydrate Polymers, 87 (2012) 1863-1868.

Abdel-Sabour MF, Ismail AS,Abou Naga H (1996) Environmental Impact of Cairo Sewage Emuent on EI-Gabal EI-Asfer Farm. Egypt. J. Soil Sci. 36 , No. 1-4, pp.329-342.

Ahmad HR, Sabir M, Rehman MZ, Aziz T, Maqsood MA, Ayub MA, Shahzad A (2020) Wastewater Irrigation-Sourced Plant Nutrition: Concerns and Prospects. In: T. Aftab, K. R. Hakeem (Ed.), Plant Micronutrients, https://doi.org/10.1007/978-3030-49856-6_18, Springer Nature Switzerland AG 2020, p. 417-434.

Ali M, Abdel-Hameed AH, Farid IM, Abbas MHH, Abbas HH (2016) To what extent can complimentary irrigation of wheat with wastewater, on soils along Belbais drain, affect soils? J. Soil Sci. and Agric Eng., Mansoura University.7 (6), 409-416. doi:
$10.21608 /$ jssae. 2016.39673

Anah L, AstriniN (2017) Influence of $\mathrm{pH}$ on $\mathrm{Cr}(\mathrm{VI})$ ions removal from aqueous solutions using carboxymethyl cellulose-based hydrogel as adsorbent. IOP Conference Series: Earth and Environmental Science. 60. 012010. 10.1088/17551315/60/1/012010.

Asano T, Smith RG, Tchobanoglous G (2018) Municipal wastewater: Treatment and reclaimed water characteristics. Irrig. With Reclaimed Munic. Wastewater-A Guid. Man. 2-26.

Attia BB (2004) Water as a basic human right in Egypt.2004. Global Issue Papers, No. 11. Heinrich Böll Foundation 2004.

Bassouny M, Abbas M, Mohamed I (2020) Environmental risks associated with the leakage of untreated wastewater in industrial Areas. Egyptian Journal of Soil Science, doi: 10.21608/ ejss.2019.18787.1319

Bassouny MA, Abbas MHH (2020) Monitoring environmental pathways of trace elements in the Northern East Area of Egypt. Environment, Biodiversity and Soil Security, 4, 103-121 .doi:: 10.21608/jenvbs.2020.29403.1094

Chin K, Ting SS, Lin OH, Owi WT (2013) Extraction of Microcrystalline Cellulose from Rice Straw and Its Effect on Polyvinyl Alcohol Biocomposites Film. Proceeding of the $3^{\text {rd }}$ International Conference of Global Network for Innovative Technology 2016 (3rd IGNITE-2016) AIP Conf. Proc. 1865, 0400061-040006-6; doi: 10.1063/1.4993348.

Choukr-Allah R (2010) Arab environment: water, wastewater treatment and reuse. Chapter 7. p.107124.

De Gisi S, Lofrano G, Grassi M, Notarnicola M (2016) Characteristics and adsorption capacities of lowcost sorbents for wastewater treatment: A review. Sustainable Materials and Technologies, 9 (2016) $10-40$.

Deshmukh PD, KhadseGK,ShindeVM,Labhasetwar $\mathrm{P}(2017)$ Cadmium Removal from Aqueous Solutions Using Dried Banana Peels as An Adsorbent: Kinetics and Equilibrium Modeling. $J$ Bioremediat Biodegrad, 8: 3, 1000395- 7 pages

El Shazly AAA, Abbas MHH, Farid IM, Rizk MA, Mohamed I, Abbas HH, Abdelhafez AA, Soliman SM, Abdel Sabour MF (2019) Feasibility of using natural mineral ores for removing $\mathrm{Cs}$ and Sr from contaminated water. Ecotoxicology and 
Environmental Safety 175, 173-180. https://doi. org/10.1016/j.ecoenv.2019.03.044

El. Nono MA, Abdel-SabourMF,El Helew WK,Ali M (2015) Removal of $\mathrm{Cu}$ (II) and $\mathrm{Pb}$ (II) from Aqueous Solution Using treated Rice straw. International Journal of Advanced Research, 3, 12, 1260 - 1271.

Elbana TA, Bakr N, Elbana M (2017) Reuse of Treated Wastewater in Egypt: Challenges and Opportunities. In: Negm A. (eds) Unconventional Water Resources and Agriculture in Egypt. The Handbook of Environmental Chemistry, vol 75. Springer, Cham. https://doi.org/10.1007/698_2017_46

El-Naggar ME, Radwan EK, El-Wakeel ST, Kafafy H, Gad-Allah TA, El-Kalliny AS, Shaheen TI (2018) Synthesis, characterization and adsorption properties of microcrystalline cellulose based nanogel for dyes and heavy metals removal. International Journal of Biological Macromolecules, 113, Pages 248-258.

El-Ramady H, Alshaal T, El-Henawy A, Abdalla N, Taha H, El-Mahrouk M, Shalaby T, Elsakhawy T, Omara A, El-Marsafawy S, Elhawat N, Shehata S (2017) Environmental Nanoremediation under Changing Climate. Environment, Biodiversity and Soil Security, 1. 190-200. 10.21608/ jenvbs.2017.1550.1009.

Farid I, Abbas M, Bassouny M, Gameel A, Abbas $H$ (2019) Indirect impacts of irrigation with low quality water on the environmental safety. Egyptian Journal of Soil Science, doi: 10.21608/ ejss.2019.15434.1294

Fathy M, MousaMA, Abdel Moghny TH, ElBellihi AA, AbdouMM,Awadallah AE (2015) Synthesis and Characterization of Cellulose Nanoparticles Obtained from Rice Straw Waste. International Journal of Modern Organic Chemistry, 4 (1): 5661 .

Fu B,Xie F (2020) Facile in situ synthesis of cellulose microcrystalline-manganese dioxide nanocomposite for effective removal of $\mathrm{Pb}$ (II) and $\mathrm{Cd}(\mathrm{II})$ from water. Environmental Science and Pollution Research 27: 5108-5121 https://doi.org/10.1007/s11356-019-07159-7.

Garba ZN, Lawan I, Zhou W, Zhang M, Wang L, Yuan Z (2019) Microcrystalline cellulose (MCC) based materials as emerging adsorbents for the removal of dyes and heavy metals - A review. Sci Total Environ. 15; 717:135070. doi: 10.1016/j. scitotenv.2019.135070.

Hashim TA, Abbas HH, Farid IM, El-Husseiny OH,
AbbasM (2017) Accumulation of some heavy metals in plants and soils adjacent to Cairo Alexandria agricultural highway. Egypt. J. Soil Sci. 57 (2), 215- 232. https://doi.org/10.21608/ ejss.2016.281.1047

Hassan NU, Mahmood Q, Waseem A, Irshad M, Pervez A(2013) Assessment of Heavy Metals in Wheat Plants Irrigated with Contaminated Wastewater. Introduction Pol. J. Environ. Stud., 22, 1, 115-123

Ibrahim MM, El-Zawawy WK,Jüttke Y,Koschella A, Heinze T (2013) Cellulose and microcrystalline cellulose from rice straw and banana plant waste: preparation and characterization. Cellulose, 20: 2403-2416. DOI 10.1007/s10570-013-9992-5.

Ibrahim ZK, Abdel-Hameed AH, Farid IM, Abbas $\mathrm{MHH}$, Abbas HH (2016) Implications of using Belbais drain water for irrigation of wheat in the North East region of Egypt. J. Soil Sci. and Agric Eng., Mansoura University., 7 (3),1-12. http:// dx.doi.org/10.21608/jssae.2016.39394

Järvenpää J (2019) Suitability of microcrystalline cellulose as an ion exchanger. Radiochemistry, University of Helsinki. Dec 2019.

Kaur M, Kumari S, Sharma P (2020) Removal of Pb (II) from aqueous solution using nanoadsorbent of Oryza sativa husk: Isotherm, kinetic and thermodynamic studies. Biotechnology Reports, 25, e00410.

Kunusa WR, Isa I, Laliyo LAR,Iyabu H (2018) FTIR, XRD and SEM Analysis of Microcrystalline Cellulose (MCC) Fibers from Corncorbs in Alkaline Treatment. IOP Conf. Series: Journal of Physics: Conf. Series 1028, 012199.

Mohamed I, Ali M, Ahmed N, Abbas MHH, Abdelsalam M, Azab A, Raleve D, Fang C (2018) Cow manure-loaded biochar changes $\mathrm{Cd}$ fractionation and phytotoxicity for wheat in a natural acidic contaminated soil. Ecotoxicity and Environmental Safety, 162: 348-353. https://doi.org/10.1016/j. ecoenv.2018.06.065

Mosa AA, El-Ghamry A, Al-Zahrani H, Selim EM, ElKhateeb A (2017) Chemically Modified Biochar Derived from Cotton Stalks: Characterization and Assessing Its Potential for Heavy Metals Removal from Wastewater. Env. Biodiv. Soil Security, 1, 3345

Nassar MA, Shakankery MH (2014) Improvement of Paper Properties of Rice Straw Pulps by Microcrystalline Cellulose/Calcium Carbonate. 
International Research Journal of Pure \& Applied Chemistry, 4 (6): 871-879.

Singha AS, Guleria A(2014) Chemical modification of cellulosic biopolymer and its use in removal of heavy metal ions from wastewater. International Journal of Biological Macromolecules 67, 409417.

Thakur M, Sharma A, Ahlawat V, Bhattacharya M, Goswami S (2020) Process optimization for the production of cellulose nanocrystals from rice straw derived a-cellulose. Materials Science for Energy Technologies, 3, 328-334 